UDC 615.012.1: 582.949.2: 581.3

DOI 10.32900/2312-8402-2020-124-4-14

\title{
THE ANTIMICROBIAL ACTIVITY OF ETHANOLIC EXTRACTS DERIVED FROM LEAVES AND PSEUDOBULBS OF COELOGYNE FLACCIDA LINDL. (ORCHIDACEAE) AGAINST DIFFERENT STAPHYLOCOCCUS AUREUSSTRAINS
}

Buyun L., Doctor of Biological Sciences

Kovalska L., Ph.D.

Gyrenko O., a post-graduate student

M. M. Gryshko National Botanic Garden, National Academy of Science of Ukraine,

Tkachenko H., Doctor of Biological Sciences

Kurhaluk N., Doctor of Biological Sciences

Institute of Biology and Earth Sciences, Pomeranian University in Słupsk

The present study was conducted to investigate in vitro antimicrobial activity of ethanolic extracts obtained from leaves and pseudobulbsof Coelogyneflaccida against Staphylococcus aureus subsp. aureus Rosenbach (ATCC ${ }^{\circledR} 25923^{\mathrm{TM}}$ ) (mecA negative), Staphylococcus aureus subsp. aureus Rosenbach (ATCC $\left.{ }^{\circledR} 29213^{\mathrm{TM}}\right)$ (mecA negative, Oxacillin sensitive, weak $\beta$-lactamase-producing strain), Staphylococcus aureus NCTC 12493 (mecA positive, Methicillin-resistant, EUCAST QC strain for cefoxitin).The antimicrobial susceptibility testing was done on Muller-Hinton agar by the disc diffusion method (Kirby-Bauer disk diffusion susceptibility test protocol). The leaves and pseudobulbs of C. flaccida plants, cultivated under glasshouse conditions, were sampled at M.M. Gryshko National Botanic Garden (NBG), National Academy of Science of Ukraine. Freshly leaves and pseudobulbs were washed, weighed, crushed, and homogenized in 96\% ethanol (in proportion 1:19) at room temperature. The extracts were then filtered and investigated for their antimicrobial activity.

The cultivation medium was trypticase soy agar (Oxoid $\mathrm{TM}, U K$ ), supplemented with $10 \%$ defibrinated sheep blood. Cultures were grown aerobically for 24 h at $37^{\circ} \mathrm{C}$. The cultures were later diluted with a sterile solution of $0.9 \%$ normal saline to approximate the density of 0.5 McFarland standard. The McFarland standard was prepared by inoculating colonies of the bacterial test strain in sterile saline and adjusting the cell density to the specified concentration.

The examined ethanolic extracts obtained from leaves and pseudobulbs of $C$. flaccida showed remarkable antibacterial activities against different $S$. aureusstrains. The observed activity may contribute to the reasons why orchids are used for infectious and inflammatory conditions in ethnomedicine. The research showed that ethanolic extracts of C. flaccida possess the highest antibacterial potency against S. aureus NCTC 12493 strain. These findings led the authors to suggest that these extracts may be used as natural antiseptics and antimicrobial agents in medicine and veterinary practice. Nevertheless, despite the promising results, more research should be carried out to further evaluate the roles of particular compounds, isolated from all parts of orchid plants, attributable to antimicrobial activity.

Keywords: antimicrobial activity, extracts, orchids, Coelogyne, Staphylococcus aureus strains, disk diffusion method

Staphylococcus aureus is an opportunistic pathogen causing a wide range of acquired infections with high morbidity [1]. Diseases caused by the Gram-positive bacterium range from skin infections to life-threatening illnesses, such as septicemia, pneu- 
monia, endocarditis, meningitis $[1,13,18]$. This is in part due to its ability to adhere to the surface of indwelling medical devices (e.g. catheter) and develop biofilm, a multilayered structure comprising of bacterial communities embedded within the extracellular hydrated polymeric matrix [20]. A biofilm is a natural form of bacterial growth ubiquitously in environmental niches. In particular, biofilm production by $S$. aureus has been identified as an important factor of pathogenesis, protecting against the immune system and antibiotics, and is considered to be responsible for chronic or persistent infections. It was shown that bacteria living in biofilms show a highly elevated pattern of adaptive resistance to antibiotics and other disinfectants [21]. Bacterial biofilms are known to cause more than $75 \%$ of microbial infections in humans [14].

$S$. aureus has long been associated with livestock. Livestock can be carriers of $S$. aureus, but can also become infected. The best-known infection is bovine mastitis [15]. An increasing number of reported detections of methicillin-resistant S. aureus (MRSA) in food animals has led to the assumption that there is an emerging zoonotic problem with livestock-associated (la)MRSA potentially aggravating the MRSA problem in humans [24]. Pigs are often carriers and are only rarely infected [24]. In chickens, several disease manifestations have been described, such as comb necrosis [25], bacterial chondronecrosis, which is a cause of leg weakness and lameness [22], and septicemia [23]. Bacterial chondronecrosis associated with $S$. aureus has been identified as an important cause of leg weakness in commercial broilers [22]. These diseases may affect a significant proportion of a flock [15].

Over $50 \%$ of all modern drugs are of natural product origin and they play an important role in drug development programs of the pharmaceutical industry [2]. Moreover, the significance of plant-derived medicines has been increasing all over the world. Since PérezGutiérrez (2010) highlighted the importance of orchid species as a source of active compounds, interest in orchid properties has been growing [27]. A wide range of chemical compounds has been identified from medicinal orchids [29].

Pseudobulbs are the most commonly used parts of orchid plants to cure various disorders, followed by leaves, roots, tubers/rhizomes, and flowers. Major local uses include aphrodisiacs, energizers, and treatments of skin burns, fractured or dislocated bones (both of humans and cattle), headaches, fever, and wounds. Other uses include insect repellent, blood purifier, skin fungi, antidote against snake bites and scorpion stings, inducement of abortions, and recovery from childbirth. Moreover, many species of the Orchidaceae family also possess antimicrobial activity [19]. Orchids are mainly used as paste, powder, or juice, solely or mixed with milk, honey, or wheat flour. Orchid extracts are either consumed orally or applied externally. Fresh orchid flowers are used to induce vomiting by exposure to a dominant foul smell. Local communities in India and Nepal also commonly eat freshly cut species of Coelogyne in the forest when they feel thirsty [29].

Therefore, this study aimed to evaluate the antimicrobial activity of the crude extracts obtained from leaves and pseudobulbs of Coelogyneflaccida (Blume) Lindl. against different Staphylococcus aureusstrains, clinically important microorganisms responsible for many infections, to support the use of these extracts as novel natural products for compounded bacterial-treatment modalities.C.flaccida belongs to section Flaccidae, distributed from mainland Southeast Asia (Thailand), all over Malesia to the islands in the Pacific Ocean [17].

Materials and methods. Collection of Plant Material. The leaves and pseudobulbs of $C$. flaccida plants, cultivated under glasshouse conditions, were sampled at M.M. Gryshko National Botanic Garden (NBG), National Academy of Science of Ukraine (Fig. 1). Since 1999, the whole collection of tropical and subtropical plants (in- 
cluding orchids) has the status of a National Heritage Collection of Ukraine. Besides that, the NBG collection of tropical orchids was registered at the Administrative Organ of CITES in Ukraine (Ministry of Environmental Protection, registration No. 6939/19/1-10, June 23, 2004).

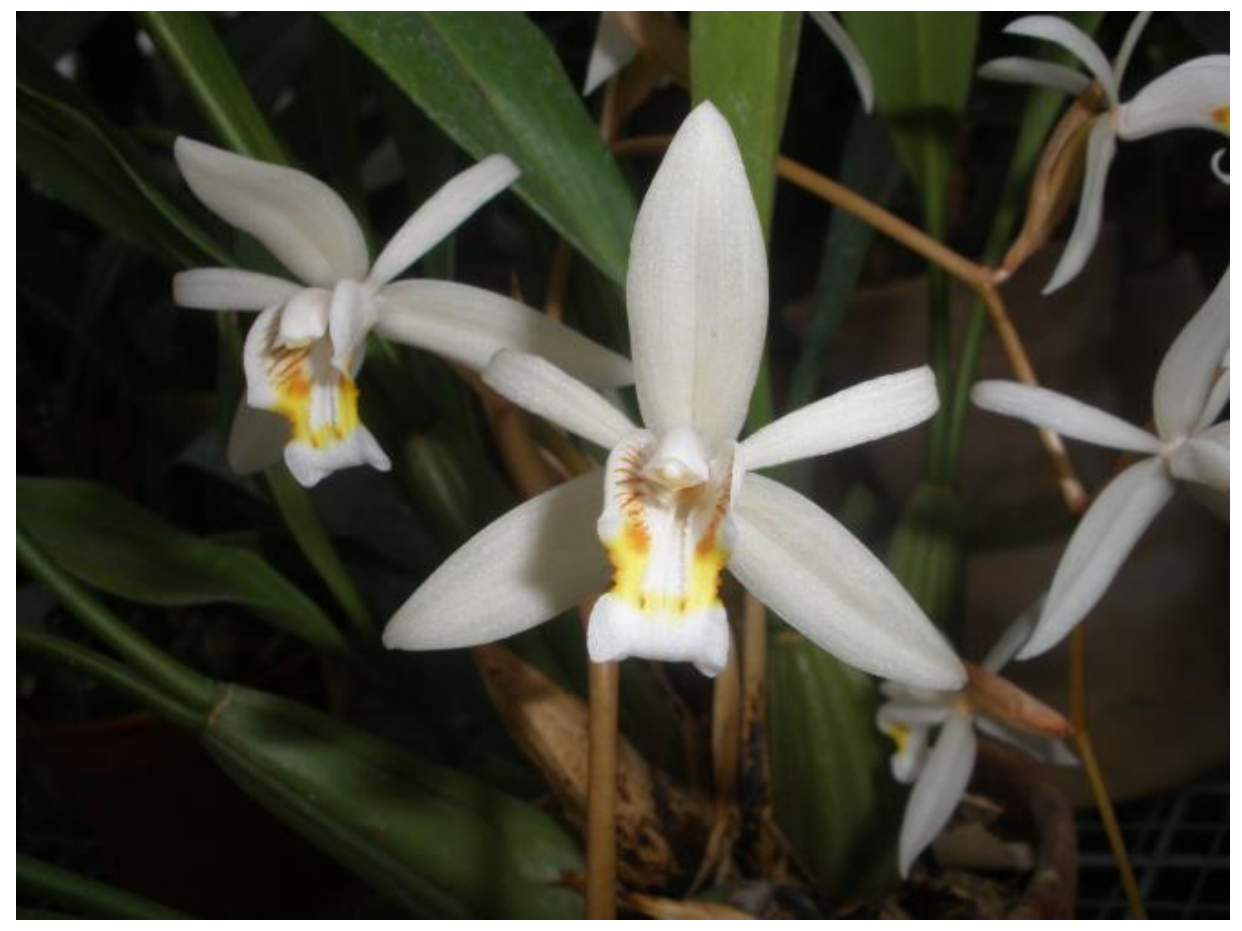

Fig. 1. The general views of flowers of Coelogyne species screened for antibacterial activity. All plant specimens are cultivated under glasshouse conditions at NBG. (Photo by Lyudmyla I. Buyun)

Preparation of Plant Extracts. Freshly leaves and pseudobulbs were washed, weighed, crushed, and homogenized in 96\% ethanol (in proportion 1:19) at room temperature. The extracts were then filtered and investigated for their antimicrobial activity.

Bacterial test strains and growth conditions. For the current study, a panel of organisms including Staphylococcus aureus subsp. aureus Rosenbach (ATCC ${ }^{\circledR} 25923^{\mathrm{TM}}$ ) (mecA negative), Staphylococcus aureus subsp. aureus Rosenbach $\left(\right.$ ATCC $\left.^{\circledR} 29213^{\mathrm{TM}}\right)($ mecA negative, Oxacillin sensitive, weak $\beta$-lactamase-producing strain), S. aureus NCTC 12493 (mecA positive, Methicillin-resistant, EUCAST QC strain for cefoxitin) were used. The cultivation medium was trypticase soy agar (Oxoid $^{\mathrm{TM}}$, UK), supplemented with $10 \%$ defibrinated sheep blood. Cultures were grown aerobically for $24 \mathrm{~h}$ at $37^{\circ} \mathrm{C}$. The cultures were later diluted with a sterile solution of $0.9 \%$ normal saline to approximate the density of $0.5 \mathrm{McF}$ arland standard. The McFarland standard was prepared by inoculating colonies of the bacterial test strain in sterile saline and adjusting the cell density to the specified concentration.

The Disk Diffusion Method for Evaluation of Antibacterial Activity of Plant Extracts. Strain tested was plated on TSA medium (Tryptone Soy Agar) and incubated for $24 \mathrm{~h}$ at $37^{\circ} \mathrm{C}$. Then the suspension of microorganisms was suspended in sterile PBS and the turbidity adjusted equivalent to that of a $0.5 \mathrm{McFarland}$ standard. The antimicrobial susceptibility testing was done on Muller-Hinton agar by the disc diffusion method (Kirby-Bauer disk diffusion susceptibility test protocol) [3]. Muller-Hinton agar plates 
were inoculated with $200 \mu$ of standardized inoculum $\left(10^{8} \mathrm{CFU} / \mathrm{mL}\right)$ of the bacterium and spread with sterile swabs.

Sterile filter paper discs impregnated by extracts were applied over each of the culture plates, 15 min after bacteria suspension was placed. A negative control disc impregnated by sterile $96 \%$ ethanol was used in each experiment. After culturing bacteria on Mueller-Hinton agar, the disks were placed on the same plates and incubated for 24 $\mathrm{h}$ at $37^{\circ} \mathrm{C}$. The assessment of antimicrobial activity was based on the measurement of the diameter of the inhibition zone formed around the disks. The diameters of the inhibition zones were measured in millimeters and compared with those of the control and standard susceptibility disks. The activity was evidenced by the presence of a zone of inhibition surrounding the well.

Statistical analysis. Zone diameters were determined and averaged. Statistical analysis of the data obtained was performed by employing the mean. All variables were randomized according to the phytochemical activity of extracts tested. All statistical calculation was performed on separate data from each extract and each strain. The data were analyzed using a one-way analysis of variance (ANOVA) using Statistica software, version 8.0 (StatSoft, Poland) [32]. The following zone diameter criteria were used to assign susceptibility or resistance of bacteria to the phytochemicals tested: Susceptible $(\mathrm{S}) \geq 15 \mathrm{~mm}$, Intermediate $(\mathrm{I})=10-15 \mathrm{~mm}$, and Resistant $(\mathrm{R}) \leq 10 \mathrm{~mm}[26]$.

Results and discussion. Ethanolic extracts obtained from leaves and pseudobulbs of Coelogyneflaccida resulted in considerable suppression of the growth of different $S$. aureus strains. Moreover, differential efficacy on the test organisms was noted between extracts obtained from leaves and pseudobulbs tested. Consequently, the extracts from various parts of plants displayed varied antibacterial potency against different $S$. aureus strains (Figs 2 and 3 ).

Inhibition zone diameters

口Leaves 口Pseudobulbs

Staphylococcus aureus NCTC 12493

$16,1^{*}$

$18,5^{*}$

Control (96\% ethanol)

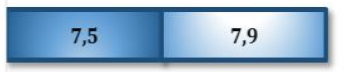

Staphylococcus aureus subsp. aureus ATCC@ $29213^{\mathrm{m}}$

$13,5 *$

$13,8 *$

Control (96\% ethanol)

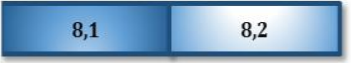

Staphylococcus aureus subsp. aureus ATCC $\left(25923^{\text {Tm }}\right.$

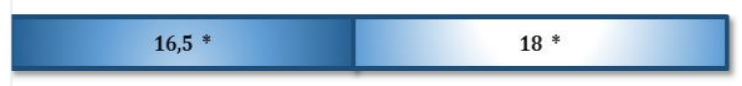

Control (96\% ethanol)

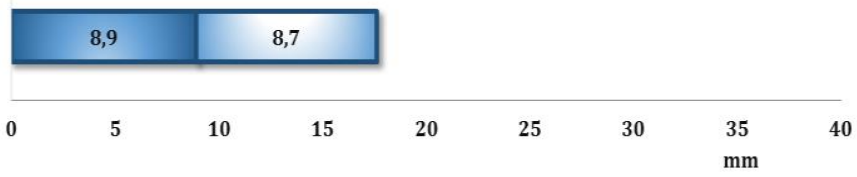

Fig. 2. Antimicrobial activity of ethanolic extracts obtained from leaves and pseudobulbs of $C$. flaccidaagainst different Staphylococcus aureusstrains measured as inhibition zone diameters formed around the disks impregnated by extracts. 
Detailed data regarding the zones of inhibition by extracts obtained from leaves and pseudobulbs of $C$. flaccidaagainst different $S$. aureusstrains were recorded and presented in Fig. 3.

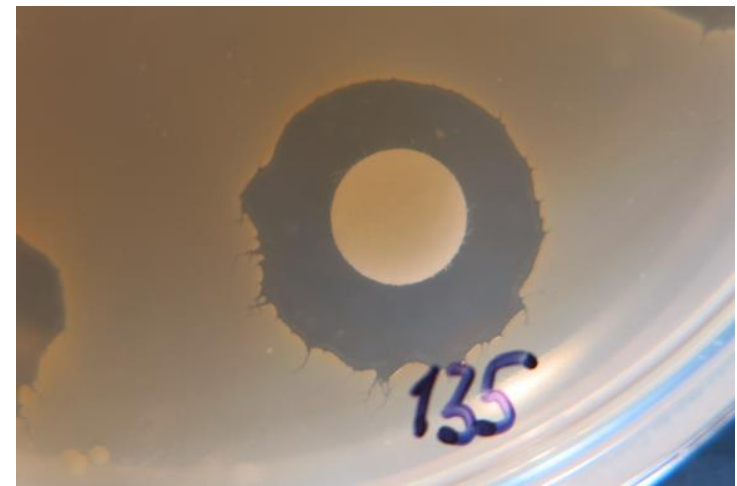

A

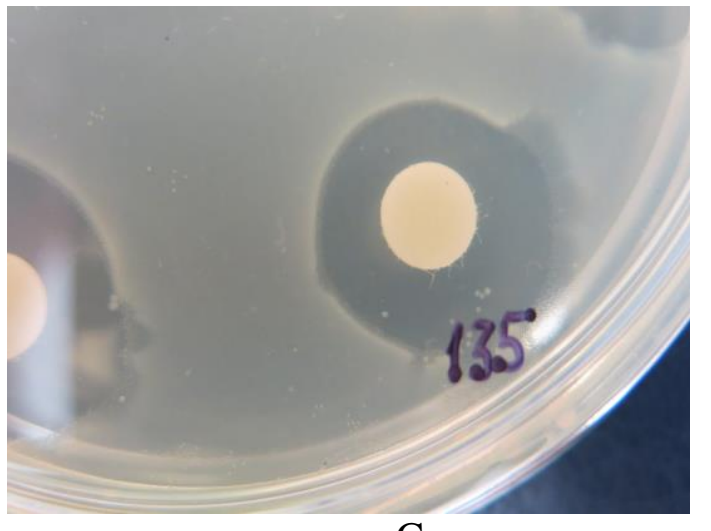

$\mathrm{C}$

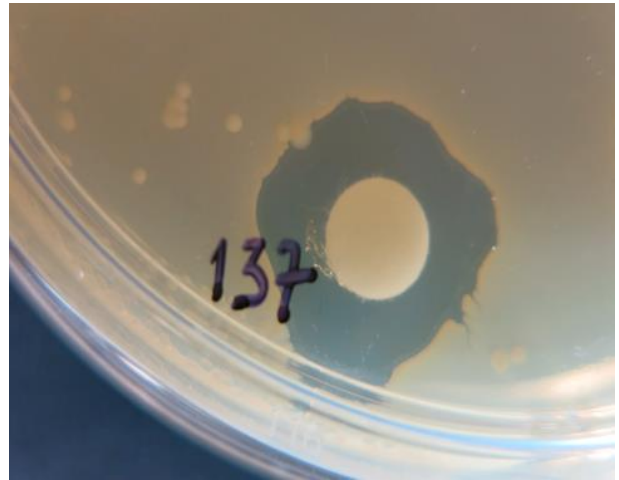

B

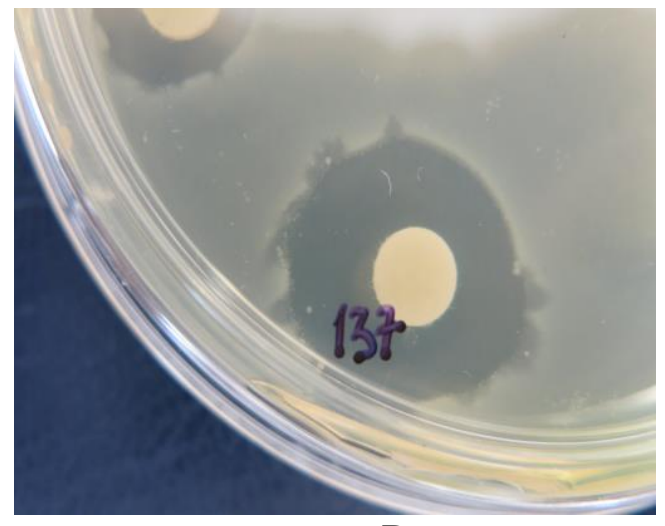

D

Fig. 2. Antibacterial spectrum of ethanolic extracts obtained from C. flaccidaagainst Staphylococcus aureus subsp. aureus $\left(\mathrm{ATCC}^{\circledR}\right.$ 25923 $\left.^{\mathrm{TM}}\right)(\mathrm{A}$ - leaves, B - pseudobulbs), S. aureus NCTC 12493 strain (C - leaves, D - pseudobulbs) measured as inhibition zone diameter

In the present study, the effect of extracts obtained from leaves and pseudobulbs of $C$. flaccida on the growth of $S$. aureuss trains was investigated in vitro. The results revealed the antimicrobial potential of these ethanolic extracts. The strains tested were susceptible to ethanolic extracts with inhibition zone diameter ranged from 12.5 to 20 mm (Figs 2 and 3).

In our study, the marked antibacterial efficacy of ethanolic extracts obtained from leaves and pseudobulbs of $C$. flaccidawas observed against Staphylococcus aureus subsp. aureus $\left(\mathrm{ATCC}^{\circledR} 25923^{\mathrm{TM}}\right.$ ) strain (mean diameter of inhibition zones was $16.5 \pm$ $1.2 \mathrm{~mm}$ and $18.0 \pm 1.1 \mathrm{~mm}$, respectively), Staphylococcus aureus subsp. aureus $\left(\right.$ ATCC $\left.^{\circledR} 29213^{\mathrm{TM}}\right)$ (mean diameter of inhibition zones was $13.5 \pm 1.2 \mathrm{~mm}$ and $13.8 \pm$ $1.0 \mathrm{~mm}$, respectively), and $S$. aureus NCTC 12493 (mean diameter of inhibition zones was $16.1 \pm 0.9 \mathrm{~mm}$ and $18.5 \pm 1.3 \mathrm{~mm}$, respectively). A statistically significant increase $(\mathrm{p}<0.05)$ in the inhibition zone diameters for Staphylococcus aureus subsp. aureus (ATCC $^{\circledR} 25923^{\mathrm{TM}}$ ) growth was $85.4 \%$ (for leaves-derived extract) and $106.9 \%$ (for pseudobulb-derived extract), for Staphylococcus aureus subsp. aureus (ATCC ${ }^{\circledR}$ $29213^{\mathrm{TM}}$ ) growth was $66.7 \%$ (for leaves-derived extract) and $68.3 \%$ (for pseudobulbderived extract), for S. aureus NCTC 12493 strain growth was $114.7 \%$ (for leavesderived extract) and $134.2 \%$ (for pseudobulb-derived extract). 
The results obtained from the present study are consistent with earlier reports, which found that other species of Coelogyne have noticeable phytochemical, antimicrobial, antioxidant, and anticancer activity [28]. In our previous study [4-12, 16, 30, 31], we have reinforced the assumption that Coelogyne species could be a potential antibacterial or antifungal resource. The orchid extracts from various species of the Coelogyne genus displayed varied antimicrobial and antifungal potency. We have determined the antifungal potential of eleven species of orchids namely $C$. viscosaLindl., $C$. cristataLindl., C. lawrenceana Rolfe, C. pandurata Lindl., C. assamica Linden \& Rchb.f., C. fimbriata Lindl., C. ovalis Lindl., C. asperata Lindl., C. flaccida (Blume) Lindl., $C$. tomentosa Lindl., and C. brachyptera Rchb. f. against Candida albicans [31]. Moreover, ethanolic orchid leaf extracts resulted in considerable suppression of the growth of $S$. aureus[30]. Among orchids selected, marked antimicrobial efficacy was observed for C. cristata (mean diameter of growth of inhibition zones was $27.5 \mathrm{~mm}$ ), C. tomentosa (26 mm), C. lawrenceana (26 mm), C. brachyptera (26 mm), C. viscosa $(25.5 \mathrm{~mm}), C$. pandurata $(24.5 \mathrm{~mm})$, and $C$. fimbriata $(24 \mathrm{~mm})$. Thus, our results showed that different extracts of epiphytic orchids from the Coelogyne genus have potent antimicrobial properties against $S$. aureus [30].

Previously, we have also investigated the antibacterial effects of ethanolic extract of $C$. brachyptera leaves against specific Gram-positive ( $S$. aureus ATCC 25923 and methicillin-resistant $S$. aureus locally isolated) and Gram-negative bacteria (Pseudomonas aeruginosa ATCC 27853 and E. coli ATCC 25922) as well as fungal strain (Candida albicans) [12]. Our results showed that the ethanolic extract of $C$. brachyptera leaves showed strong activity against the Gram-positive bacterial strains (20 mm diameter of inhibition zone for $S$. aureus and $26 \mathrm{~mm}$ for methicillin-resistant $S$. aureus), and mild activity against Gram-negative bacteria ( $14 \mathrm{~mm}$ for E. coli and $11 \mathrm{~mm}$ for P. aeruginosa). Extract of $C$. brachyptera has displayed strong inhibitory activity against test fungus C.albicans (mean diameter of inhibition zone was $17.2 \mathrm{~mm}$ ) [12]. The ethanolic extract of $C$. ovalis leaves also showed strong activity against $S$. aureus $(27 \mathrm{~mm}$ of inhibition zone diameter), while the ethanolic extract from pseudobulbs revealed less activity $(22 \mathrm{~mm})$. Methanolic and ethyl acetate extracts obtained from $C$. ovalis leaves also showed appreciable antimicrobial activity $(32 \mathrm{~mm}$ and $35 \mathrm{~mm}$, respectively), whereas those extracts from pseudobulbs revealed no antibacterial activity against $S$. aureus [4].

Previously, we have also investigated the antibacterial effects of ethanolic extracts obtained from leaves and pseudobulbs of plants belonging to the Coelogyne genus [7, 8]. For example, the antifungal potential of eight species of orchids, i.e. Coelogynecristata Lindl., C. fimbriata Lindl., C. flaccidaLindl., C. huettneriana Rchb.f., C. ovalis Lindl., C. speciosa (Blume) Lindl., C. tomentosa Lindl. and C. viscosaLindl. against fungus strain, Candida albicans was determined in the study of Buyun and coworkers (2018). Marked antifungal efficacy was observed in the case of ethanolic extracts derived from leaves of $C$. flaccida (mean diameter of inhibition zones was 19.5 $\mathrm{mm})$, C. viscosa $(18.6 \mathrm{~mm})$, C. huettneriana $(18.2 \mathrm{~mm})$, and C. fimbriata $(17.5 \mathrm{~mm})$. Extracts of $C$. cristata, $C$. ovalis, and $C$. tomentosa displayed less inhibitory activity against test fungus (mean diameter of inhibition zones ranging from 16 to $17.5 \mathrm{~mm}$ ). The ethanolic extracts from the pseudobulbs of eight species from the Coelogyne genus exhibited strong activity against $C$. albicans (inhibition zone diameter ranged from 16 to $23.5 \mathrm{~mm}$ ). Moreover, it has been observed that ethanolic extract obtained from pseudobulbs of $C$. speciosa revealed the highest antibacterial activity $(21 \mathrm{~mm}$ as the diameter of the inhibition zone) among various species from the Coelogynegenus. The results also indicate that scientific studies carried out on medicinal plants having traditional claims of effectiveness might warrant fruitful results [7, 31]. 
Also, the results obtained from the present research showed the antimicrobial potential of $C$. flaccida extracts against different $S$. aureusstrains. So, ethanolic extracts can be used as antiseptics and antimicrobial agents in medicine and veterinary. The antibacterial activity in Coelogyne may be due to the presence of alkaloids, bibenzyl derivatives, flavonoids, phenanthrenes, and terpenoids. Clinical studies confirmed diuretic, anti-rheumatic, anti-inflammatory, anti-carcinogenic, antimicrobial, anticonvulsive, relaxation, neuro-protective, and antivirus activities [27].

The presence of these phytochemicals provides antimicrobial, antitumor, antiinflammatory, antiviral activities, etc. Several members of the orchid family are used as a potent inhibitor against bacteria and also proved to be a potent antimicrobial agent. The methanolic extract from different parts of orchids has shown antimicrobial activity. A broad-spectrum antibacterial activity ( 24 bacteria and protozoan) was exhibited by Galeolafoliata leaves and stem bark extracted with petrol, dichloromethane, ethyl acetate, butanol, and methanol. A very good level of activity was demonstrated by the dichloromethane and ethyl acetate fractions [19].

Conclusions. The examined ethanolic extracts obtained from leaves and pseudobulbs of $C$. flaccida showed remarkable antibacterial activities against different $S$. aureusstrains. The observed activity may contribute to the reasons why orchids are used for infectious and inflammatory conditions in ethnomedicine. The research showed that ethanolic extracts of $C$. flaccida possess the highest antibacterial potency against $S$. $a u$ reus NCTC 12493 strain. These findings led the authors to suggest that these extracts may be used as natural antiseptics and antimicrobial agents in medicine and veterinary practice. Nevertheless, despite the promising results, more research should be carried out to further evaluate the roles of particular compounds, isolated from all parts of orchid plants, attributable to antimicrobial activity.

\section{References}

1. Al-Mebairik, N. F., El-Kersh, T. A., Al-Sheikh, Y. A., \& Marie, M. A. M. (2016). A review of virulence factors, pathogenesis, and antibiotic resistance in Staphylococcus aureus. Rev. Med. Microbiol., 27, 50-56.

2. Baker, J. T., Borris, R. P., Carte, B., Cordell, G. A., \& Soejarto, D. D. (1995). Natural product drug discovery and development: New perspective on international collaboration. J. Natl. Prod., 58, 1325-1357.

3. Bauer, A. W., Kirby, W. M., Sherris, J. C., \& Turck, M. (1966). Antibiotic susceptibility testing by a standardized single disk method. Am. J. Clin. Pathol., 45 (4), 493-496.

4. Buyun, L., Tkachenko, H., Kovalska, L., \& Osadowski, Z. (2016). Preliminary screening of Coelogyneovalis Lindl. (Orchidaceae) for antimicrobial activity against Staphylococcus aureus. Days of laboratory medicine: proceedings of the Republican scientific and practical conference. Ed. V.V. Vorobyov (p. 10). Grodno : GRSMU.

5. Buyun, L., Tkachenko, H., \& Osadowski, Z. (2016). Antimicrobial activities of the various extracts obtained from leaves and pseudobulbs of Coelogynetomentosa Lindl. (Orchidaceae). III International Scientific and Practical Conference of Students, Postgraduates and Young Scientists "Ecology - Philosophy of Human Existence", dedicated to the $30^{\text {th }}$ anniversary of the Chernobyl disaster, National University of Life and Environmental Sciences of Ukraine, April 26-28, 2016. (pp. 10-12). Kyiv.

6. Buyun, L., Tkachenko, H., Osadowski, Z., Góralczyk, A., Kovalska, L., \& Gyrenko, O. (2016). Antimicrobial screening of the various extracts derived from the 
leaves and pseudobulbs of Coelogynespeciosa(Blume) Lindl. (Orchidaceae). Stupskie Prace Biologiczne, 13, 37-54.

7. Buyun, L., Tkachenko, H., Osadowski, Z., Góralczyk, A., Kovalska, L., \& Gyrenko, O. (2018). Evaluation of antifungal efficacy of ethanolic extracts obtained from vegetative organs of some epiphytic orchids from CoelogyneLindl. genus against Candida albicans. Stupskie Prace Biologiczne, 15, 39-58.

8. Buyun, L., Tkachenko, H., Kurhaluk, N., Gyrenko, O., Kovalska, L., Góralczyk, A., Tomin, V., \& Osadowski, Z. (2019). Antibacterial Activity of the Ethanolic Extracts Derived from Leaves and Pseudobulbs of Some Orchids Belonging to Coelogyne Genus Against Enterobacter cloacae Strain. Agrobiodiversity for Improving Nutrition, Health, and Life Quality, (3), 348-360.

9. Buyun L., Tkachenko H., Osadowski Z., \& Kovalska L. (2016). Antimicrobial activities of the various extracts obtained from leaves and pseudobulbs of Coelogynehuettneriana Rchb.f. (Orchidaceae). Ontogenesis - state, problems and prospects of studying plants in cultural and natural cenoses : Proceedings of International. conferences dedicated to the $110^{\text {th }}$ anniversary of the birth of the Dean of the Agronomy Faculty Lipes Veniamin Elevich (June 10-11, 2016) (pp.. 8-11). Kherson : RVC "Kolos"

10. Buyun, L., Tkachenko, H., Osadowski, Z., Kovalska, L., \& Gyrenko, O. (2016). Antimicrobial activity screening of extracts from leaves and pseudobulbs of Coelogynecristata Lindl. (Orchidaceae). Scientific proceedings of the international network AgroBioNet of the institution and researcher of international research, education and development programme "Agrobiodiversity for improving nutrition, health, and life quality 2016“. Slovak University of Agriculture in Nitra, Nitra, November 2016 (pp. 40-44).

11. Buyun, L., Tkachenko, H., Osadowski, Z., Kovalska, L., \& Gyrenko, O. (2017). The antimicrobial properties of the various extracts derived from the pseudobulbs of Coelogynespeciosa (Blume) Lindl. (Orchidaceae) against Staphylococcus aureus. Agrobiodiversity for improving nutrition, health and life quality, 1, 43-49.

12. Buyun, L. I., Tkachenko, H. M., \& Osadowski, Z. (2016). Antibacterial and antifungal activity of the ethanolic extract from Coelogynebrachyptera Rchb. f. leaves (Orchidaceae). Proceedings of the International Scientific and Practical Conference "Sustainable technologies and the legal economic aspects of agricultural production", National University of Life and Environmental Sciences of Ukraine (April 27-28, 2016) (pp. 133-135). Kyiv

13. Chen, B.-C., Lin, C.-X., Chen, N.-P., Gao, C.-X., Zhao, Y.-J., \& Qian, C.-D. (2018). Phenanthrene antibiotic targets bacterial membranes and kills Staphylococcus aureus with a low propensity for resistance development. Front. Microbiol., 9, 1593.

14. Costerton, J. W., Stewart, P. S., \& Greenberg, E. P. (1999). Bacterial biofilms : a common cause of persistent infections. Science, 284, 1318-1322.

15. Fluit, A. C. (2012). Livestock-associated Staphylococcus aureus. Clin. Microbiol. Infect., 18(8), 735-744.

16. Góralczyk, A., Tkachenko, H., Buyun, L., \& Osadowski, Z. (2016). The antimicrobial potential of ethanolic extract of Coelogynecristata Lindl. (Orchidaceae) leaves. Youth and Progress of Biology : Book of Abstracts of XII International Scientific Conference for Students and Ph.D. Students (Lviv, April 19-21, 2016) (pp. 259260). Lviv

17. Gravendeel, B. (2000). Reorganising the orchid genus Coelogyne: a phylogenetic classification based on morphology and molecules. Leiden (Netherlands), Leiden University 
18. Hogan, S., Zapotoczna, M., Stevens, N. T., Humphreys, H., O'Gara, J. P., \& O'Neill, E. (2016). Eradication of Staphylococcus aureus catheter-related biofilm infections using ML : 8 and Citrox. Antimicrob. Agents Chemother., 60, 5968-5975.

19. Khan M. R., \& Omoloso A. D. (2004). Antibacterial activity of Galeolafoliata. Fitoterapia, 75(5), 494-496.

20. Kong, C., Chee, C. F., Richter, K., Thomas, N., Abd Rahman, N., \& Nathan, S. (2018). Suppression of Staphylococcus aureus biofilm formation and virulence by a benzimidazole derivative, UM-C162. Sci. Rep., 8 (1), 2758.

21. Lu, L., Hu, W., Tian, Z., Yuan, D., Yi, G., Zhou, Y., Cheng, Q., \& Zhu, J., Li, M. (2019). Developing natural products as potential anti-biofilm agents. Chinese Medicine, 14, 11.

22. McNamee, P. T., McCullagh, J. J., Thorp, B. H., Ball, H. J., Graham, D., McCullough, S. J., McConaghy, D., \& Smyth, J. A. (1998). Study of leg weakness in two commercial broiler flocks. Vet. Rec., 143(5), 131-135.

23. McNamee, P. T., \& Smyth, J. A. (2000). Bacterial chondronecrosis with osteomyelitis ('femoral head necrosis') of broiler chickens: a review. Avian Pathol., 29(5), 477-495.

24. Meemken, D., Blaha, T., Tegeler, R., Tenhagen, B. A., Guerra, B., Hammerl, J. A., Hertwig, S., Käsbohrer, A., Appel, B., \& Fetsch, A. (2010). Livestock associated methicillin-resistant Staphylococcus aureus (LaMRSA) isolated from lesions of pigs at necropsy in northwest Germany between 2004 and 2007. Zoonoses Public Health, 57(7-8), e143-e148.

25. Nakamura, K., Shirai, J., Imai, K., Hihara, H., \& Tanimura, N. (1997). Outbreak of comb necrosis in layer breeder chickens. Avian Dis., 41(1), 252-256.

26. Okoth, D. A., Chenia, H. Y., \& Koorbanally, N. A. (2013). Antibacterial and antioxidant activities of flavonoids from Lanneaalata (Engl.) Engl. (Anacardiaceae). Phytochem. Lett., 6, 476-481.

27. Pérez Gutiérrez, P. R. M. (2010). Orchids: A review of uses in traditional medicine, its phytochemistry and pharmacology. Journal of Medicinal Plants Research, 4(8), 592-638.

28. SahayaShibu, B., Chitra Devi, B., SarmadMoin, L., \& Servin Wesley, P. (2013). Evaluation of bioactive potential of Coelogyne nervosa A. Rich. - an endemic medicinal orchid of western Ghats, India. Asian J. Pharm. Clin. Res., 6 (1), 114-118.

29. Subedi, A. (2011). New species, pollinator interactions and pharmaceutical potential of Himalayan orchids. Ph.D. Thesis, Leiden University, The Netherlands.

30. Tkachenko, H. M., Trukhan, M. A., Buyun, L. I., Shon, Kh. N., \& Chiong, M. (2016). Antibacterial efficacy of some orchid species of the genus CoelogyneLindl. in relation to Staphylococcus aureus. Proceedings of the N.I. Pirogov XI International (XX All-Russian) scientific medical conference of students and young scientists. Russian National Research Medical University named after N.I. Pirogov (March 17, 2016) (pp. 632-633). Moscow

31. Tkachenko, H., Truchan, M., Buyun, L., Kovalska, L., \& Gyrenko, A. (2015). Antifungal efficacy of some orchids from CoelogyneLindl. genus against Candida albicans. Abstracts of the International Scientific and Practical Conference of Scientists, Postgraduates and Students "Integrated Plant Protection and Quarantine. Prospects for development in the XXI century", National University of Life and Environmental Sciences of Ukraine, (November 19-20, 2015) (pp. 178-181). Kyiv

32. Zar, J. H. (1999). Biostatistical Analysis. $4^{\text {th }}$ ed., Prentice-Hall Inc., Englewood Cliffs, New Jersey. 
АНТИМИКРОБНАЯ АКТИВНОСТЬ СПИРТОВЫХ ЭКСТРАКТОВ, ПОЛУЧЕННЫХ ИЗ ЛИСТЬЕВ И ПСЕВДОБУЛЬБ COELOGYNE FLACCIDA LINDL. (ORCHIDACEAE) OTHОСИТЕЛЬНО РАЗЛИЧНЫХ ШТАММОВ STAPHYLOCOCCUS AUREUS

Людмила Буюн, Людмила Ковальская, Александр Гиренко, Наџиональный ботанический сад им. Н. Н. Гришко НАН Украины, Киев, Украина

Галина Ткаченко, Наталия Кургалюк, Институт биологии и наук о Земле, Поморская Академия в Слупске, Польша

Целью нашего исследования было изучение антимикробной активности in vitro этанольных экстрактов, полученных из листьев и псевдобульб Cоеlogynе flaccida Lindl. в отношении Staphylococcus aureus subsp. aureus Rosenbach (ATCC ${ }^{\circledR} 25923^{\mathrm{TM})}$ (тесA-отрииательный), Staphylococcus aureus subsp. aureus Rosenbach (ATCC ${ }^{\circledR} 29213^{\mathrm{TM})}$ (тесA-отрицательный, чувствительный к оксациллину, штамм, продуцирующий слабую $\beta$-лактамазу), Staphylococcus aureus NCTC 12493 (тесA-положительный, метициллин-резистентный, штамм EUCAST QC для иеефокситина). Листья и псевдоклубни растений C. flaccida, культивировали в тепличных условиях, они были отобраны в Начиональном ботаническом саду им. Н.Н. Гришко Начиональной академии наук Украинь. Свежие листья и псевдоклубни промывали, взвешивали, измельчали и гомогенизировали в 96\% этаноле (в пропориии 1:19) при комнатной температуре. Затем экстракты фильтровали и исследовали их антимикробную активность.

Питательной средой служил триптиказо-соевый агар (Oxоіd Тм, Великобритания), дополненный $10 \%$-ной дефибрированной овечьей кровью при $37{ }^{\circ} \mathrm{C}$. $3 a$ тем культуры разбавляли стерильным раствором 0,9 \% нормального физиологического раствора, чтобы приблизить плотность до 0,5 стандарта Макфарланда. Стандарт McFarland готовили путем инокулячии колоний тест-штамма бактерий в стерильном физиологическом растворе и подгонки плотности клеток до заданной кониентращии.

Тестирование противомикробной чувствительности к препаратам проводилось на агаре Мюллера-Хинтона методом дисковой диффузии (протокол теста на чувствительность Кирби-Бауэра). Исследованные этанольные экстракmbl, полученные из листьев и псевдобульб C. flaccida, показали высокую антибактериальную активность относительно различных итаммов S. аитеиs. Наблюдаемая активность может быть одной из причин, по которым орхидеи используются при инфекционных и воспалительных заболеваниях в этномедицине.

Исследования показали, что этанольные экстракты C. flaccida обладают наивысшей антибактериальной активностью в отношении штамма S. aитеиs NCTC 12493, и могут использоваться в качестве естественных антисептиков $и$ антимикробных средств в медииине и животноводстве. Вместе с тем, несмотря на многообещающие результаты, необходимо провести дополнительные исследования для дальнейшей оченки роли конкретных соединений, выделенных из всех частей растений орхидеи, обусловленных антимикробной активностью.

Ключевые слова: антимикробная активность, экстракты, орхидные, Coelogyne, штаммы Staphylococcus aureus, диско-диффузионный метод 
АНТИМІКРОБНА АКТИВНІСТЬ СПИРТОВИХ ЕКСТРАКТІВ, ОТРИМАНИХ 3 ЛИСТЯ I ПСЕВДОБУЛЬБ СОЕLOGYNE FLACCIDA LINDL. (ORCHIDACEAE) ЩОДО РIЗНИХ ШТАMIB STAPHYLOCOCCUS AUREUS

Буюн Л., Ковальська Л., Гиренко О., Наџіональний ботанічний сад ім. М. М. Гришка НАН Украӥни, Київ, Украӥна

Ткаченко Г., Кургалюк Н., Інститут біологї̈ та наук про Землю, Поморська Академія в Слупську, Польща

Метою дослідження було вивчення антимікробної активності in vitro етанольних екстрактів, отриманих з листя i псевдобульб Coelogyne flaccida Lindl. щуодо Staphylococcus aureus subsp. aureus Rosenbach (ATCC®25923 ${ }^{\mathrm{TM}}$ ) (тесA-негативний), Staphylococcus aureus subsp. aureus Rosenbach (АТСС®29213 Тм) (тесА-негативний, чутливий до оксациліну, штам, який продукує слабку $\beta$-лактамазу), Staphylococcus aureus NCTC 12493 (тесA-позитивний, метицилін-резистентний, штам EUCAST QC для иеефокситину). Листя і псевдобульби рослин C. flaccida, культивованих в тепличних умовах, були відібрані в Націіональному ботанічному саду ім. М. М. Гришко Національної академії наук Украйни. Свіже листя і псевдобульби промивали, зважували, подрібнювали і гомогенізували в 96\% етанолі (в пропориії 1:19) при кімнатній температурі. Потім екстракти фільтрували і досліджували їх антимікробну активність.

Живильним середовищем служив триптиказо-соєвий агар (Oxoid тм , Beликобританія), доповнений 10\%-ною дефібринованою овечою кров'ю. Культури вирощували аеробно протягом 24 год. при $37^{\circ} \mathrm{C}$. Потім культури розбавляли стерильним розчином 0,9\% нормального фізіологічного розчину, щоб наблизити щільність до 0,5 стандарту Макфарланда. Стандарт McFarland готували иляхом інокуляиії колоній тест-итаму бактерій в стерильному фізіологічному розчині $i$ підгонки щзільності клітин до заданої концентращії.

Тестування протимікробної чутливості до препаратів проводилося на агарі Мюллера-Хинтона методом дискової дифузї (протокол тесту на чутливість Кірбі-Бауера). Досліджені етанольні екстракти, отримані з листя і псевдобульб C. flaccida, показали високу антибактеріальну активність щзодо різних итамів $S$. aureus. Cпостережувана активність може сприяти тому, що орхідеї використовуються при інфекційних $і$ запальних станах в етномедицині.

Дослідження показали, щзо етанольні екстракти C. flaccida мають найбільшу антибактеріальну активність відносно штаму S. aureus NCTC 12493. Ці результати привели авторів до припущення, щуо ичі екстракти можуть бути використані в якості природних антисептиків $і$ антимікробних засобів в медицині $i$ тваринництві. Проте, незважаючи на багатообіияючі результати, необхідно провести додаткові дослідження для подальшої очінки ролі конкретних сполук, виділених з усіх частин рослин орхідеї, обумовлених антимікробною активністю.

Ключові слова: антимікробна активність, екстракти, орхідні, Coelogynе, штами Staphylococcus aureus, діско-діфузний метод 